\title{
Model of Corporate Social Responsibility (CSR) Gold Mining for Community Empowerment Batangtoru District of South Tapanuli in North Sumatra Province
}

\author{
Arifin Saleh $^{1}$, Ahmad Hidayah Dalimunthe ${ }^{2}$ \\ ${ }^{1}$ Lecturer in Social Welfare Science, Faculty of Social and Political Science, University of Muhammadiyah \\ Sumatra Utara (UMSU), Indonesia \\ ${ }^{2}$ Lecturer in State Administration, Faculty of Social and Political Science, University of Muhammadiyah \\ Sumatra Utara (UMSU), Indonesia
}

\begin{abstract}
Gold mining company PT. Agincourt Resources (PT. AR), which manages the Martabe Gold Mine in Batangtoru District, South Tapanuli Regency, North Sumatra Province, implements corporate social responsibility or Corporate Social Responsibility (CSR). The CSR program is implemented to help those who are classified as poor in the Batangtoru Subdistrict, which is still around 7,019 or 23.7\% of the total population. This study aims to obtain a CSR model that is suitable for PT. AR in realizing the empowerment of the Batangtoru community. The expected result is the existence of a CSR model for gold mining for community empowerment. Research methods with a combined quantitative and qualitative approach. This study focused on 15 villages / kelurahan directly affected by mining with a population of 5,086 families and a sample of 370 households. Quantitative data analysis with Structural Equation Modeling (SEM), using IBM ${ }^{\circledR}$ SPSS ${ }^{\circledR}$ Amos 22 software. Qualitative data with typological data analysis. The results of the study show the implementation of CSR PT. Agincourt Resources has a positive influence and can lead to an increase in community empowerment and the multiplier effect of the company's presence. The CSR model that is suitable and suitable for gold mining companies for community empowerment is by implementing CSR in the health sector, strengthening the family economy, social assistance, infrastructure, and education which is then directed to fields related to community empowerment, such as education level, quality of health facilities, employment, economic centers, infrastructure, increased family assets, increased income, ability to work together, and the ability to obtain information and communication.
\end{abstract}

Keywords: corporate social responsibility (CSR); community empowerment; gold mining

\section{Introduction}

Corporate Social Responsibility (CSR) is a genuine effort from business entities to minimize negative impacts and maximize the positive impact of its operations on all stakeholders (Rachman et al, 2011). CSR is widely regarded as a binding responsibility that is feasible to ensure the creation of sustainable benefits for the company and society (Urip, 2014). Gold mining company PT. Agincourt Resources (PT. AR), which manages the Martabe Gold Mine in Batangtoru District, South Tapanuli Regency, North Sumatra Province has long implemented CSR. In the exploration phase, the company has issued CSR funds amounting to Rp. 6.02 billion more (Saleh and Basit, 2012). After the company enters the production stage in the sense that mining has produced gold, the CSR budget spent each year 
is far increased. Data from Comrel PT. AR, from 2013 to May 2015, the CSR funds distributed by Rp. 56.61 billion more. The fund budget is used for various activities such as socialization of mining activities, health assistance, assistance for places of worship, educational assistance, infrastructure assistance, assistance for victims of natural disasters, local economic development, and community relations. The Martabe Gold Mine has an area of 1,639 square kilometers, with potential resources of 8.05 million oz of gold and 77 million oz of silver. Annual capacity of 250,000 oz of gold and 2-3 million oz of silver (GResources.net). If $1 \mathrm{oz}$ is equivalent to 28.35 grams, the company's gold capacity reaches $7,087,000$ grams or 7,087 tons. If it is converted to a gold price of Rp.500,000 per gram today, then gold will be valued at Rp.3.5 trillion per year. Silver potential reaches 84 million grams and if converted to silver prices today Rp.11,000 per gram, silver will be worth Rp. 924 billion per year. CSR activities carried out by PT. The AR must be able to empower the community, especially the poor. This is because there are still many people who are classified as poor in Batangtoru District, where the gold mining company operates. There are still 7,019 people or $23.7 \%$ of the population classified as poor from 29,517 residents in Batangtoru District (BPS Tapanuli Selatan, 2012). The development of Batangtoru Subdistrict is also not significant.

Then there has not been a new economic center. The market as an economic center or economic center in Batangtoru does not increase, there is only one namely Batangtoru Market. Then the week which takes place weekly also only exists in two places, namely Wek II Village and Huta Godang Village. In the health sector, even though the Puskesmas has been developed and now occupies a new building, the company supports CSR, but infrastructure and services still need to be improved. Including the addition of health care facilities in the form of a Auxiliary Health Center (Pustu) which until now in Batangtoru is still 3 units. In agriculture, the yield of rice production is decreasing. In 2008 rice production reached 25,645 tons, in 2013 it dropped to 14,544 tons (Statistics Coordinator of Batangtoru District, Tapanuli Selatan District, 2013). This can mean that CSR activities conducted by PT. AR still needs to be improved and maximized. PT CSR activities. AR towards the community is considered not optimal because it is more of a assistance, not in the context of community empowerment. These CSR activities have not been able to bring the community to a stage called powerless or independent (Saleh and Lutfi, 2012).

Based on the background above, the author is interested in conducting research related to the CSR model of PT. AR for community empowerment in Batangtoru District, South Tapanuli Regency, North Sumatra Province. This research will support national development goals and also the achievement of the North Sumatra Muhammadiyah University Strategic Plan (UMSU) and in accordance with the university research roadmap. One of the research issues or themes in the UMSU college research roadmap is the field of Policy, National Integration, and Social. In the UMSU research roadmap, the issue or theme raised in this study is in accordance with the design that runs from 2016 to 2021 (LPPM UMSU, 2016).

\subsection{Formulation Of The Problem}

The formulation of the problem in this study is as follows:

1. What is the influence of CSR gold mining PT. AR on community empowerment in Batangtoru District, South Tapanuli Regency, North Sumatra Province?

2. What is the appropriate CSR model for PT. AR in realizing community empowerment in Batangtoru District, South Tapanuli Regency, North Sumatra Province? 


\section{Theoretical Description}

Suharto (2010) defines CSR as a concern for companies that set aside a portion of profits (profits) for the benefit of human development (people) and environment (planet) on an ongoing basis based on appropriate and professional procedures. In this case the CSR action program includes:
a. CSR in Education
b. CSR in the Health Sector
c. CSR in the Environment Sector
d. CSR in Social Capital
e. CSR in Economics and Entrepreneurship

According to Ife and Tegoriero (2008), there are at least six dimensions of community development or empowerment and all of them interact with one another. These six dimensions are; social development, economic development, political development, cultural development, environmental development, and personal / spiritual development. Soetomo (2006) explains that community empowerment or development is a planned social change, both in the economic, technological, social and political fields. Community development in a broad sense can also mean a development process that focuses more on the aspects / people and the community. In a narrow sense, community development means social planning changes in a particular locality.

Empowerment means providing resources, opportunities, vocabulary, knowledge and skills to improve the ability of the community to determine their own future and to participate and influence the lives of their people (Ife and Tesoriero, 2008). That understanding also shows that poor people must be empowered. According to Ambadar (2010), one of the highlights of CSR practices in Indonesia is the emphasis on aspects of community empowerment (Community Develompent / CD). Although CSR is not solely a CD, it does indeed fit the conditions and needs of our society, which is still struggling with poverty, the low quality of education and health which is the main cause of the difficulty of breaking the poverty chain. This research is inseparable from the results of Barrick Gold Corporation (Barrick) CSR research conducted by Newenham and Kahindi (2011), covering company policy, the balance between the ability of international businesses and companies with local communities. CSR can reduce tensions between Barrick and local communities in the company's operational zone. Skills development and education of local human resources must also be done. To be able to adjust capabilities in this era, people must be able to make changes that are more competitive by increasing their education and skills to become a keen community in capturing future-oriented opportunities (Widjajanti, 2011). This is in line with the results of Bahri's research (2010) which mentions life skills learning programs with participatory learning strategies and integrating life skills owned by each community member will help community empowerment efforts. Another research is Mujiyadi's research (2012) which mentions another alternative in community empowerment is the transfer of business, with the provision of capital loans with mild interest. With greater capital, they will be able to package their business and even increase the type of merchandise.

Strengthening social capital and economic capital must also be included in the community empowerment approach. Fuaziyah and Awang (2012) said that the condition of social capital owned by the community is directly proportional to its socioeconomic 
conditions, where in a society where social capital conditions are good, socio-economic conditions will also be good, and vice versa. Community empowerment can be done with the development of CSR models conducted by the company. This is also consistent with the research of Saleh and Lutfi (2016) who found that the development of the CSR model of the gold mining company PT Agincourt Resources could be an option in alleviating the empowerment of the poor in South Tapanuli Regency.

\section{Methods of The Research}

This study uses a combination of quantitative approaches and qualitative approaches. Research like this is commonly called joint research with a dominant dominant design approach (Creswell, 2012). This research took place in Batangtoru District, South Tapanuli Regency, North Sumatra Province and at the gold mining location of PT. AR .. The research is focused on 15 villages / kelurahan which are included in the village around the mine. The population in this study were all households or families in 15 villages around the mine which were the targets of the CSR program of PT. AR, which is 5,086 families (BPS Tapsel, 2015). The sample uses the Slovin formula (Sevilla, 2007) and the results are 370 families. Informants as resource persons were determined by purposive technique and the number according to the study approached 5 people. This study has 2 (two) variables, namely CSR $(\mathrm{X})$ as the independent variable and Community Empowerment $(\mathrm{Y})$ as the dependent variable. Both variables are divided into sub-variables with their respective indicators. Quantitative data analysis uses Structural Equation Modeling (SEM) with IBM ${ }^{\circledR}$ SPSS ${ }^{\circledR}$ Amos 22 software. Qualitative data are analyzed by compiling information and data obtained from the field and from informants by type and categorization.

\section{Results And Discussion}

\section{1 Result}

\section{a. General Overview of Batangtoru District}

Batangtoru is a sub-district in South Tapanuli Regency, North Sumatra Province, Indonesia. The capital of this sub-district is in Kelurahan Wek I. The South Tapanuli and Batangtoru regions can be seen as in Figure 5.1 below. Administratively, Batangtoru SubDistrict borders North Tapanuli Regency in the North, Central Tapanuli Regency in the west, Angkola Sangkunur District and Muara Batang Toru District in the South and Angkola Timur District in the East. Batangtoru District is an area rich in natural resources. The rubber plantation owned by PT Perkebunan Nusantara (PTPN) III is widespread in this area. In this area there is also the largest gold mine in North Sumatra managed by PT. Agincourt Resources. The topography of villages and villages in Batangtoru District ranges from flat to hilly. The distance from the village / kelurahan to the subdistrict capital ranges from 0.1 to 9 $\mathrm{Km}$. The Batangtoru region generally has a flat topography. The population of Batangtoru Subdistrict reached 31,077 people in 2014. The average population per household is 4.43 people per km2. Demographically, Batangtoru District, South Tapanuli Regency has a homogeneous population, both from religion, ethnicity, culture and customs. This encourages the establishment of an open character and a strong sense of mutual assistance in the community of Batangtoru District, South Tapanuli Regency. 


\section{b. Characteristics of Respondents}

Respondents of this study are family heads and or housewives who know and have been the target of the CSR program of PT. Agincourt Resources. Respondents in this study were 370 people. Most respondents or $57.8 \%$ were female and $42.2 \%$ were male. The majority of female respondents are housewives and know and have been involved in CSR activities of PT. Agincourt Resources, for example in the field of health programs and also training in strengthening family economics.

\section{c. Effect of PT. Agincourt Resources for Community Empowerment in Batangtoru District, South Tapanuli Regency}

This study wants to find out the direct effect of the implementation of CSR of the gold mining company PT. Agincourt Resources on community empowerment in Batangtoru District, South Tapanuli Regency. The findings indicate that the implementation of CSR of the gold mining company PT. Agincourt Resources positively predicted the Batangtoru Tapanuli Selatan community empowerment (estimated parameters $\gamma 2=0.58, \mathrm{p}<0.001$ ). From Figure 1 it can be seen that the direct influence (without intermediaries) of the CSR implementation of the gold mining company PT. Agincourt Resources in the community empowerment of Batangtoru District, South Tapanuli Regency was 0.58. In particular, previously stated relations in a moderate level were found between Family Economic Strengthening and Emerging Economic Centers $(r=0.28, p<0.01)$, Income Increase $(r=0.31, p<0.01)$, and Ability to Obtain Information and Communication (correlation $r=0.29, p<0.01$ ). This shows that the implementation of CSR PT. Agincourt Resources in the field of family economic strengthening has a positive influence, which can lead to an increase in community empowerment in Batangtoru Kabuaten District, South Tapanuli.

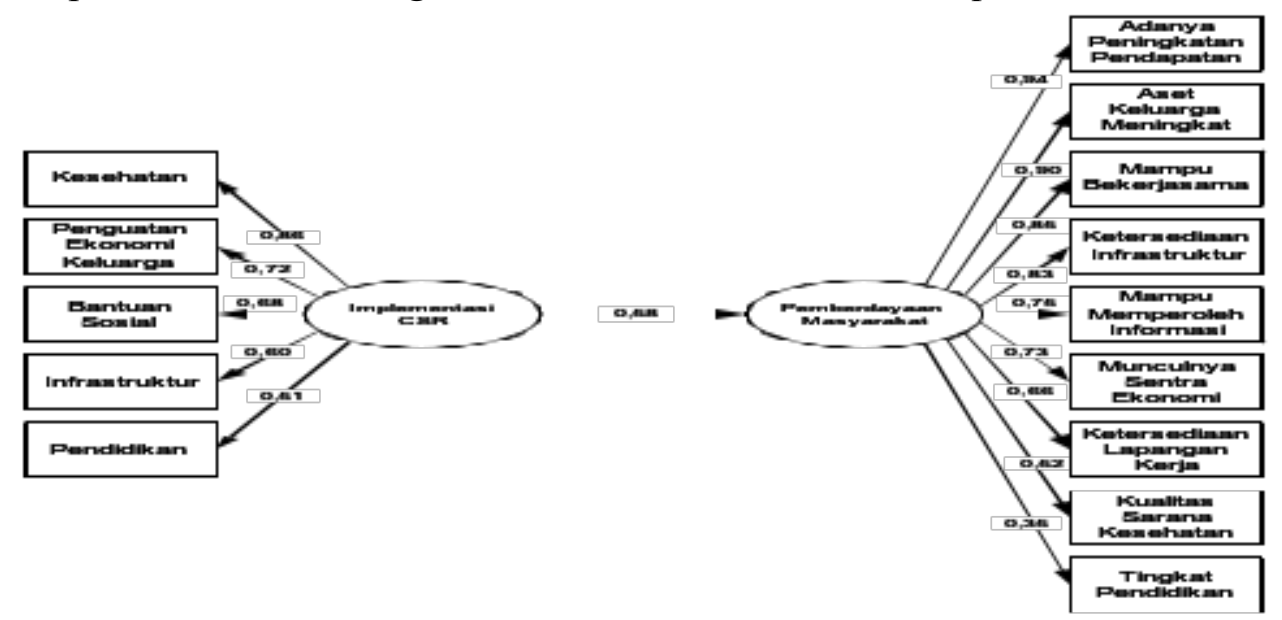

Figure 1 Effect of PT. Agincourt Resources for Community Empowerment in Batangtoru District, South Tapanuli Regency.

For example, CSR programs that help strengthen the family's economy are training in making cakes and packaging, training youth groups in the field of fisheries, training catfish cattle. In the field of information and communication, the CSR program of PT. Agincourt Resources is in the form of cooperation with professional journalist organizations, the 
formation of the Martabe Community Consultation Institute as a representative or bridge to the company with the community.

\section{d. The Gold Mining CSR Model for Community Empowerment}

The CSR model of the results of this study can be seen as follows:

Figure 2. CSR Model of the Gold Mine for Community Empowerment

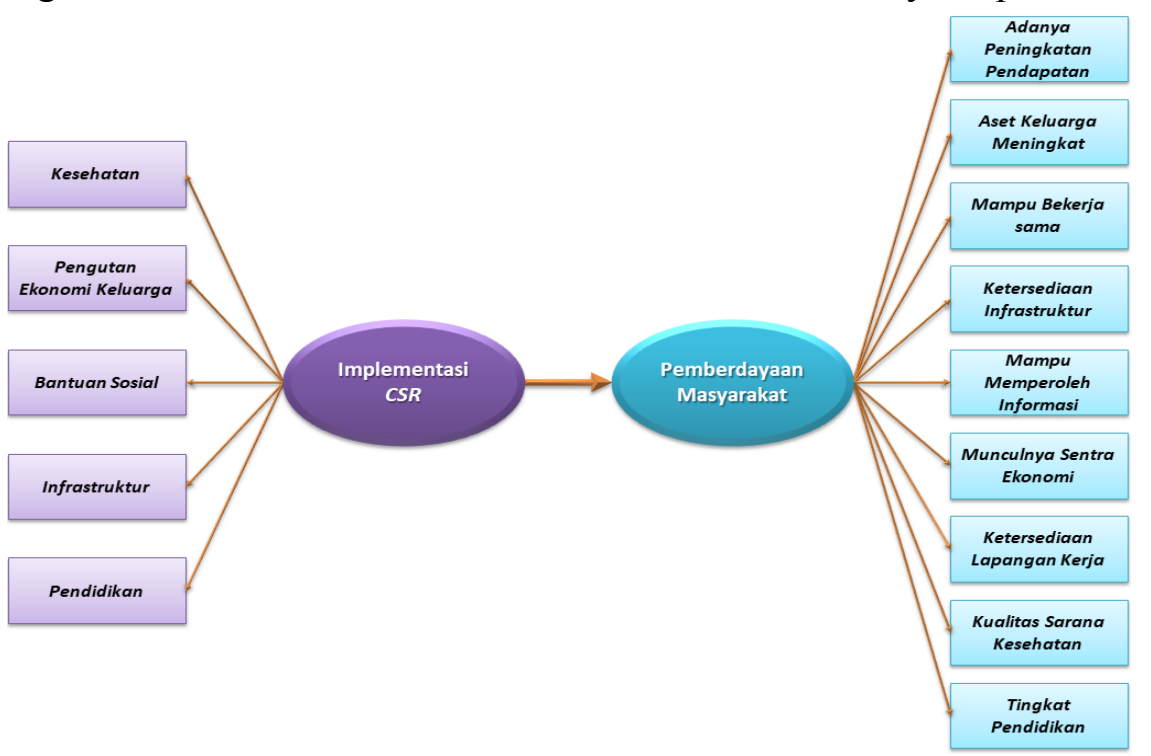

Source: Research Results, 2018

From Figure 2 above, it is clear that the PT Agincourt Resources' CSR gold CSR model for the empowerment of the Batangtoru community, South Tapanuli began with CSR implementation in several fields. In an effort to empower the Batangtoru community, it was carried out through the implementation of CSR programs which included health, strengthening the family economy, social assistance, infrastructure and education. With the implementation of CSR in these various fields, it is believed that it will be able to empower the community with the hope of rising levels of education, improvement in the quality of health facilities, availability of jobs, the emergence of economic centers, and the availability of infrastructure. Then also an increase in family assets, an increase in income, visible ability to work together, and the creation of the ability to obtain information and communication. From the results of the study revealed also that the implementation of CSR PT. Agincourt Resources, should have been carried out by involving elements of the community, government, and the company so that the three parties joined in one forum named Tri Partnership. PT. Agincourt Resources should also try to do this pattern or model so that there is synergy between the company, the community and the government.

\section{IV.2 Discussion}

PT CSR Program Agincourt Resources is very helpful to the community. Thamrin Harahap, owner of a coffee shop in Pasar Batangtoru, who was also one of the speakers in 
this study, acknowledged that the presence of mining companies was also able to increase the emergence of new economic centers. This can be seen from the existence of new businesses carried out by the community, such as the opening of restaurants, workshops, snacks such as meatballs and chicken noodles. The observations of the researchers also showed that many new businesses did appear in Batangtoru, such as restaurants, meatballs, workshops. The coffee shop owned by Thamrin Harahap also looks very crowded with visitors. Even among visitors there are also mining company employees who look complete with uniforms that read PT. Agincourt Resources. Arianto, Djumlani, and Anggraeny (2013) reported the same results in their research where the implementation of CSR in Family Economic Strengthening had a significant positive change impact on the development of the target community business through a "Father Lift" program that was managed sustainably. Some speakers said that the implementation of PT CSR.

Agincourt Resources has been useful and helped in community empowerment efforts. It's just that the CSR program still needs to be improved. Head of the South Tapanuli Department of Social, Manpower and Transmigration, Drs. Parulian Nasution, MM, who was the guest speaker in this study, claimed that the mining company's CSR program had helped community empowerment. This is one of them can be seen from the absorption of local workers who work in the company. With the acceptance of local people working in the company, of course, it will help empower themselves and their families. Parulian Nasution then said that the gold mine CSR was very useful. In addition, the company can also provide employment for the local community. In the future, CSR management should involve elements of society and government. The scope of the CSR target area should also be expanded to cover the entire South Tapanuli area so that all South Tapanuli people will enjoy it. The results of the observation (observation) of the author, the influence of the CSR program of PT. Agincourt Resources has begun to be seen as a multiplier effect of the company's presence. Several new micro and small businesses have sprung up in Batangtoru, Muara Batangtoru and surrounding districts, such as warungs, restaurants, salons, clothing stores, food stores, department stores, and cellphone buying and selling stores.

Then the establishment of rented houses and boarding houses, refill mineral water depots, pharmacies with more varied and complete drug availability, car repair services business, motorbike showrooms and motorbike credit offers to the establishment of hospitality services. This condition also encourages an increase in the number of tools and transportation flows such as motorbike rickshaws, public transportation and intercity buses, the emergence of gas stations until the establishment of telecommunication network tower providers such as Telkomsel, Indosat and XL Axiata and others. Economic excitement that arises can also be seen from the existence of financial institutions. If initially there were only BRI and Bank Sumut, currently BNI and Bank Syariah Mandiri already have branch offices in Batangtoru. It's just that, the implementation of PT CSR program. Agincourt Resources is still carried out by the company itself. In terms of, budgeting and implementation are carried out by the company through the ComRel and ComDev divisions. The pattern of implementing this CSR program is carried out by the company alone, not involving the government and the community in the official Tri Partnership container (Company, Government, and Society). In fact, the implementation of CSR should involve the community, government, and of course the company. In various regions and companies, CSR implementation has been managed in Tri Partnership. According to Latif Supriadi, in planning CSR programs still involve the 
community. The company invited community representatives to ask for input. In addition, the company also accommodates proposals and community requests submitted through proposals

\section{Conclusion}

In the context of community empowerment as a manifestation of CSR or corporate social responsibility, PT. Agincourt Resources has carried out various programs and activities in the health sector, strengthening the family economy, social assistance, infrastructure, and education.

Implementation of CSR PT. Agincourt Resources has a positive influence and can lead to an increase in community empowerment of Batangtoru Kabuaten District, South Tapanuli. The influence of PT. CSR program. Agincourt Resources is also seen from the multiplier effect of the company's presence. The CSR model that is suitable and suitable for gold mining companies for community empowerment is the implementation of CSR in the health sector, strengthening the family economy, social assistance, infrastructure, and education which is then directed to various fields related to community empowerment, such as rising education levels, improvement quality of health facilities, availability of employment opportunities, emergence of economic centers, availability of infrastructure, increased family assets, increased income, visible ability to work together, and the creation of the ability to obtain information and communication.

\section{Reference}

Ambadar, Jackie, 2010, CSR Dalam Praktek di Indonesia, PT Elex Media Komputindo, Jakarta.

Andri, 2006, Perspektif Pembangunan Wilayah Pedesaan, Jurnal Inovasi, Vol. 6 (18).

Bahri, Syaiful, 2010, Solusi Praktis Pengentasan Kemiskinan Melalui Pelatihan Keterampilan Layak Jual: Studi Deskreptif di Kelurahan Martubung Kecamatan Medan Labuhan, Jurnal AkademiaVolume 12, Medan.

[BPS] Biro Pusat Statistik, 2014, Tapanuli Selatan Dalam Angka 2013, Padangsidimpuan.

[BPS] Koordinator Statistik Kecamatan Batangtoru, 2009, Kecamatan Batangtoru Dalam Angka 2008, Koordinator Statistik Tapsel, Padangsidimpuan.

Creswell W. John, 2012, Research Design: Pendekatan Kualitatif, Kuantitatif dan Mixed, Yogyakarta, Pustaka Pelajar.

Fuaziyah, Eva dan San Afri Awang, 2012, Analisis Modal Sosial Dalam Pengembangan Usaha Hutan Rakyat, Jurnal Inovasi 9: 259, Medan.

Ife, Jim \& Tegoriero, Frank, 2008, Community Development; Alternatif Pengembangan Masyarakat di Era Globalisasi, Pustaka Pelajar, Yogyakarta.

Mujiyadi, 2012, Pemberdayaan Masyarakat Miskin Pinggiran Kota: Studi Pekerjaan Sosial tentang Petani Penggarap di Lahan Sementara, Jurnal Sosiokonsepsia 17: 201, Jakarta

Newenham, Marcus Aloysius and Kahindi, 2011, A Global Mining Corporation and Local Communities in the Lake Victoria Zone: The Case of Barrick Gold Multinational in Tanzania, Journal of Business Ethics, Volume 99:253-282.

Rachman, Nurdizal M., Asep Efendi, Emir Wicaksana, 2011, Panduan Lengkap Perencanaan CSR, Penebar Swadaya, Jakarta. 
Saleh, Arifin dan Lutfi Basit, 2013, Corporate Social Responsibility (CSR) Pertambangan Emas Agincourt Resources Dalam Pemberdayaan Masyarakat Batangtoru Kabupaten Tapanuli Selatan, Jurnal Keskap, Volume 11 Nomor 1, Fisip UMSU.

Saleh, Arifin, 2016, Urgensi Model Baru Corporate Social Responsibility (CSR) Pertambangan Emas Agincourt Resources untuk Pengembangan Wilayah Kecamatan Batangtoru, Kabupaten Tapanuli Selatan, Provinsi Sumatera Utara, Prociding Konferensi Ilmu Sosial dan Ilmu Politik, FISIP UMSU, Medan.

Saleh, Arifin dan Lutfi Basit, 2016, Pengembangan Model Corporate Social Responsibility (CSR) Agincourt Resources Dalam Pemberdayaan Masyarakat Miskin di Kabupaten Tapanuli Selatan Propinsi Sumatera Utara, Prosiding SNHP3M Untar, Volume 3 Nomor 1 Tahun 2016 dengan P-ISSN:2356-3176, Jakarta.

Soetomo, 2006, Strategi-strategi Pembangunan Masyarakat, Pustaka Pelajar, Yogyakarta.

Suharto, Edi, 2010, CSR \& Comdev, Investasi Kreatif Perusahaan di Era Globalisasi, Alfabeta, Bandung.

Urip, Sri, 2014, Strategi CSR: Tanggung Jawab Sosial Perusahaan untuk Peningkatan Daya Saing Perusahaan di Pasar Negara Berkembang, Literati Imprint, Tangerang Selatan.

Widjajanti, Kesi, 2011, Model Pemberdayaan Masyarakat, Jurnal Ekonomi Pembangunan 12: 26, Jakarta. 